\title{
SISTEM INFORMASI KEARSIPAN POLITEKNIK NEGERI PADANG BERBASIS WEB
}

\author{
Oleh : \\ Rasyidah, Yulherniwati, Ronal Hadi, Meri Azmi \\ Jurusan Teknologi Informasi Politeknik Negeri Padang \\ ronalhadi@yahoo.com
}

\begin{abstract}
The resulting of system is a web based application executed, it can be accessed by many users at the same time trough each on computer from browser by accessing the specified address. The users of this system consists of a head, department chairman, the general secretary of the department and administration of department, this system is build using PHP programming language and MySql database server. Advantages of this system is that it can save paper (paperless) and storage physical space. On this system can monitor incoming mail, incoming mail was processed, outgoing mail and letters that have been in the disposition that is in Polytecnic with available in online then this system becomes more effective performance and efficiently
\end{abstract}

Keywords : web based application,PHP, MySql

\section{PENDAHULUAN}

\section{Latar Belakang}

Politeknik Negeri Padang administrasi pengarsipan surat masih dilakukan secara manual karena data yang diproses masih berupa dokumen. Ini beresiko dokumen yang hilang, dokumen tidak bisa dilacak keberadaannya setelah dikirimkan dan memakan waktu yang lama karena proses birokrasi yang ada. Karena itu perlu dibangun suatu sistem untuk pengelolaan dan pengarsipan berkasberkas surat yang berupa aplikasi berbasis web. Sehingga proses administrasi tersebut mengarah ke paperless-work system, yaitu segala aktivitas persuratan yang masih dilakukan dengan cara verifikasi manual dapat di gantikan dengan verifikasi elektronik. Namun pada tahap awal masih dilakukan pengarsipan dokumen fisik yang dilengkapi dengan hasil scan dan data arsip yang terintegrasi dalam basisdata di server. Dengan demikian dapat memudahkan dalam pencarian arsip. Disamping itu juga dilengkapi dengan adanya notifikasi tentang surat masuk atau disposisi kepada penerima.

\section{Tujuan}

1.Dapat memudahkan tugas sekretariat dan administrasi jurusan dalam hal surat menyurat. Sehingga pekerjaan yang sebelumnya dilakukan secara manual bisa lebih efisien dan terkomputerisasi dengan baik.

2.Routing surat dan monitoring surat dapat memudahkan sekretariat dalam memanajemen surat menyurat secara teratur dan juga memudahkan pimpinan dalam mengawasi kelancaran administrasi kearsipan. 


\section{METODOLOGI PENELITIAN}

Sistem Informasi Kearsipan Politeknik Negeri Padang ini dilakukan dengan tahap-tahap sebagai berikut :

- Studi Pustaka

- Analisis Kebutuhan

- Perancangan

- Implementasi

- Pengujian

- Perbaikan

- Publikasi

- Pembuatan laporan

Berikut adalah penjelasan masingmasing tahap :

\section{Studi Pustaka}

Studi Pustaka dilakukan untuk mengumpulkan dan mempelajari referensi dan teori-teori pendukung yang berkaitan dengan aplikasi yang akan dibangun.

\section{Analisis Kebutuhan}

Analisis kebutuhan untuk mengetahui kebutuhan fungsional dan non fungsional yang diinginkan dari sistem ini.

\section{Perancangan}

Perancangan terdiri dari perancangan arsitektur, perancangan data, perancangan antarmuka dan perancangan prosedural aplikasi.

\section{Implementasi}

Aplikasi diimplementasikan menggunakan PHP pada web server dan basis data menggunakan MySQL Server.

\section{Pengujian}

Setelah aplikasi selesai dibuat, selanjutnya dilakukan pengujian. Pengujian dilakukan dengan dua cara yaitu pengujian pada komputer standalone dan pengujian pada web server di Jurusan Teknologi Informasi.

a. Pengujian Pada Komputer Stand Alone

Pengujian ini dimaksudkan untuk mengetahui apakah aplikasi dapat berjalan dengan baik. Pengujian ini dimulai dengan membuka halaman utama (index) kemudian menguji akses pengguna aplikasi dan navigasinya.

\section{b. Pengujian Pada Web Server}

Jika pengujian pada komputer stand alone telah selesai selanjutnya dilakukan pengujian dengan menempatkan aplikasi dan basisdata pada web server di Jurusan Teknologi Informasi dan diakses melalui internet.

\section{Perbaikan Aplikasi}

Berdasarkan hasil pengujian, dilakukan jika ditemukan kelemahan-kelemahan aplikasi sehingga belum memenuhi kebutuhan fungsional dan non fungsional yang ditetapkan.

\section{Publikasi}

Jika proses perbaikan telah selesai selanjutnya dilakukan publikasi pada web.

Gambar 1 memperlihatkan langkahlangkah pembangunan sistem informasi kearsipan Politeknik 


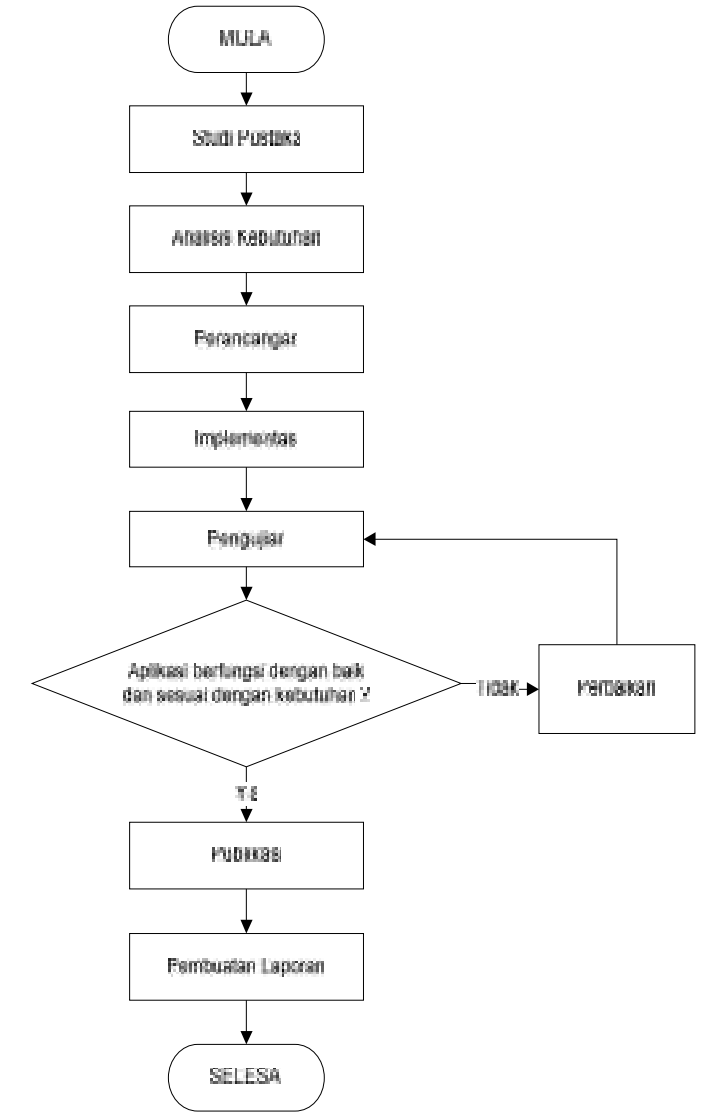

Gambar 1. Tahapan Pembangunan Aplikasi

\section{HASIL DAN PEMBAHASAN}

\section{Hasil}

Gambaran umum sistem yang dibuat ditunjukkan pada gambar 2 berikut ini :

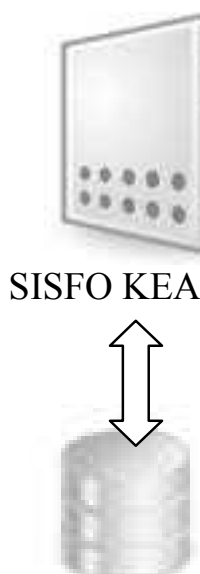

DATABASE
Gambar 2. Gambaran umum sistem informasi

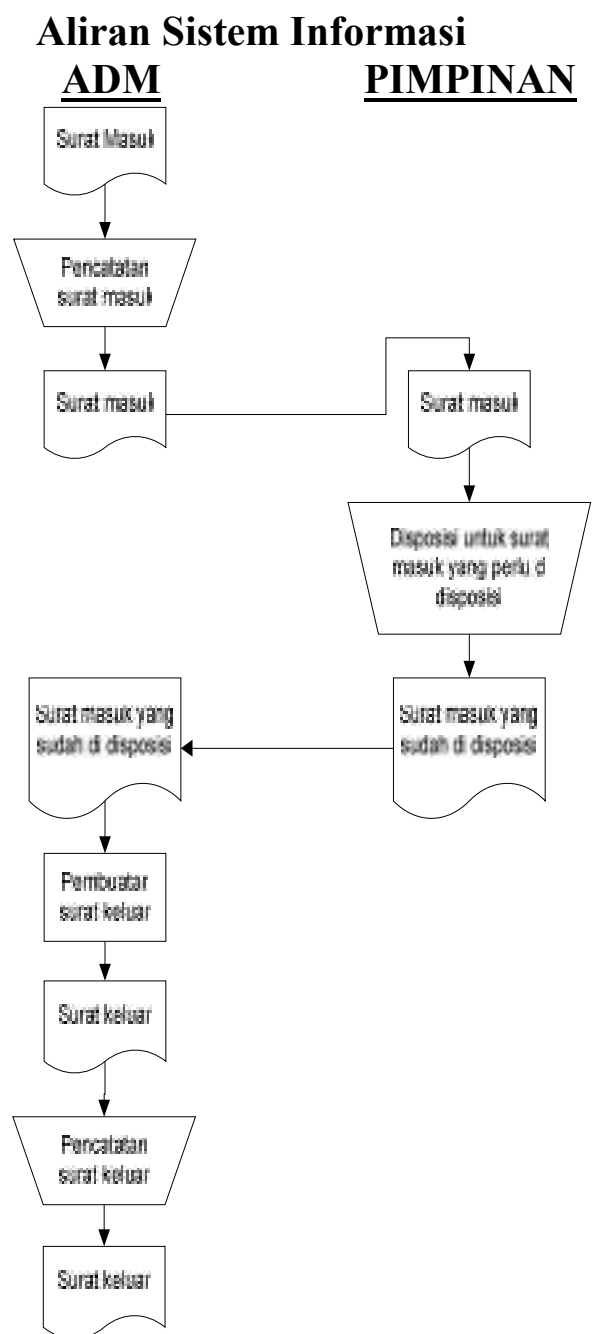

Gambar 3. Aliran umum Sistem Informasi

Sebagai pembanding, Gambar 3 adalah aliran sistem informasi sebelumnya

\section{Perangkat Lunak}

Beberapa perangkat lunak yang digunakan diantaranya adalah :

- Web Server : Apache Server

- Database Management System (DBMS) : MySQL Server

Bahasa pemrograman :PHP 


\begin{tabular}{|c|c|c|c|}
\hline & Komputer User & Web Server & Database Server \\
\hline $\begin{array}{l}\text { Operating } \\
\text { System }\end{array}$ & $\begin{array}{ll}\text { - } & \text { Windows } \\
\text { - } & \text { Linux }\end{array}$ & - Windows & - Windows \\
\hline $\begin{array}{l}\text { Special } \\
\text { Software }\end{array}$ & $\begin{array}{l}\text { - Internet Explorer, } \\
\text { Mozilla Firefox } \\
\text { atau software } \\
\text { sejenis }\end{array}$ & - Apache & - $\quad$ MySQL 5 \\
\hline Hardware & $\begin{array}{ll}\text { - } & 40 \text { giga disk drive } \\
\text { - } & \text { Pentium } \\
\text { - } & \text { Monitor } \\
\text { - } & \text { RAM } 128 \mathrm{MB}\end{array}$ & $\begin{array}{ll}\text { - } & 80 \text { giga disk drive } \\
\text { - } & \text { Pentium } \\
\text { - } & \text { RAM } 1 \text { GB }\end{array}$ & $\begin{array}{ll}- & 200 \text { giga } \\
& \text { disk drive } \\
- & \text { RAID } \\
\text { - } & \text { Quad } \\
& \text { Pentium }\end{array}$ \\
\hline Network & $\begin{array}{ll}\text { - } & \text { Dial up } \\
& \text { Connection } \\
\text { - } & \text { Wireless } \\
& \text { Connection }\end{array}$ & & $\begin{array}{l}\text { Dual } 100 \\
\text { Mbps } \\
\text { Ethernet }\end{array}$ \\
\hline
\end{tabular}

Basis data

$\begin{array}{ccc}\text { Basis data yang } \\ \text { digunakan dinamakan dbsisip } & \text { yang }\end{array}$ terdiri dari tabel Disposisi, tabel Divisi, tabel Gambar, tabel Jabatan, tabel JenisJabatan, tabel KategoriArsip, tabel Kategoripengguna, tabel Lokasiarsip, tabel Pegawai, table Pengguna, Tabel Suratkeluar dan tabel Suratmasuk. Spesifikasi masing-masing tabel diperlihatkan pada Gambar-gambar berikut ini :

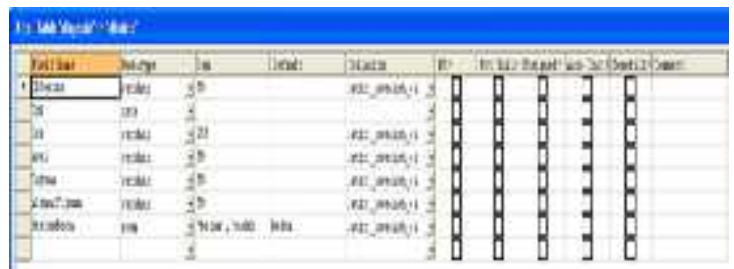

Gambar 5 Tabel Disposisi

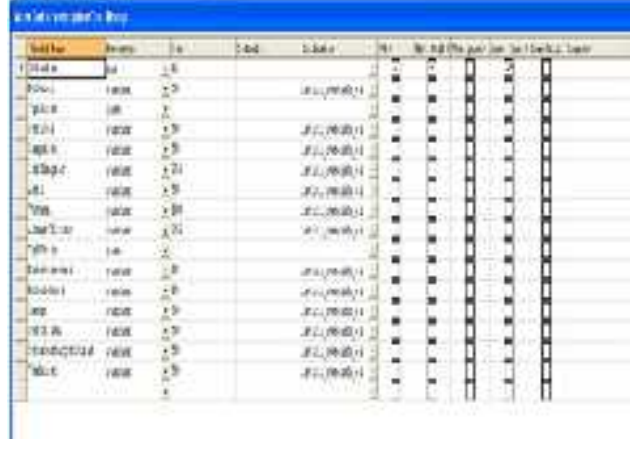

Gambar 6 Tabel Suratkeluar 


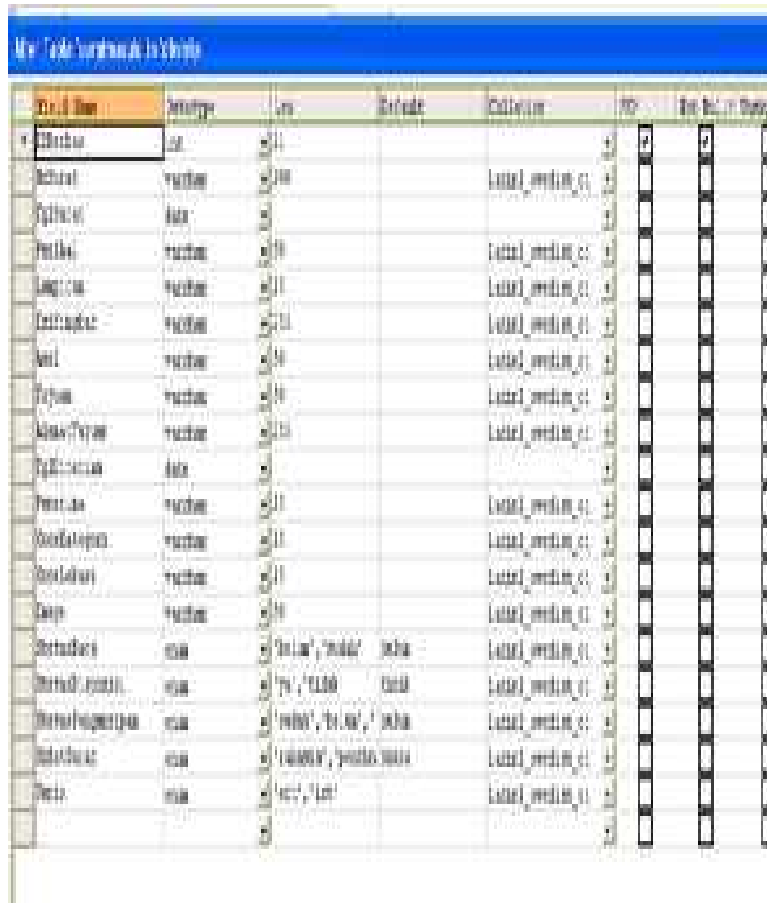

Gambar 7 Tabel Suratmasuk

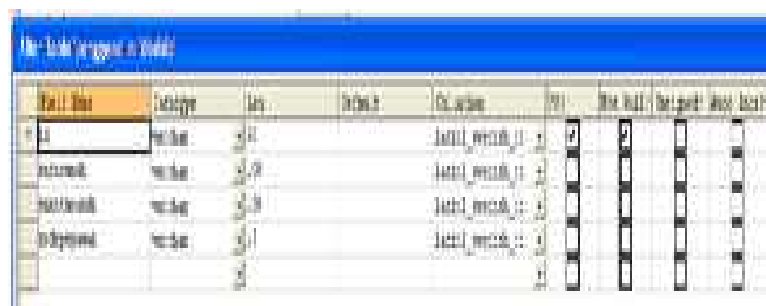

Gambar 8 Tabel Pengguna
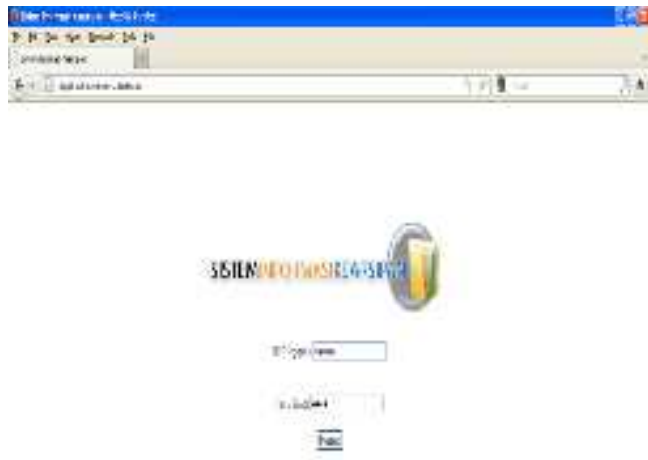

\section{Antarmuka Web}

Gambar 9 menampilkan tampilan awal sistem kearsipan online.

Pada tampilan awal sistem ini, user diharuskan untuk memasukkan ID Pengguna dan kata sandi. User disini hanya ada 2 jenis yaitu administrasi dan pimpinan, tergantung siapa yang ditunjuk sebagai administrasi dan pimpinan yang ditunjuk oleh masingmasing unit. Misalnya untuk tingkat jurusan, pimpinannya bisa terdiri dari Ketua jurusan dan sekretaris jurusan. Untuk tingkat politeknik, administarsi merupakan sekretaris direktur dan pimpinan adalah direktur.

Pada bagian administrasi bertugas mencatat surat masuk dan surat keluar, dimana surat masuk dan surat keluar tersebut di-scan kemudian di-upload ke sistem. Pimpinan dengan membuka sistem ini menjadi tahu mengenai surat masuk dan surat keluar yang ada di unit tersebut.

\section{Gambar 9 Tampilan awal sistem}




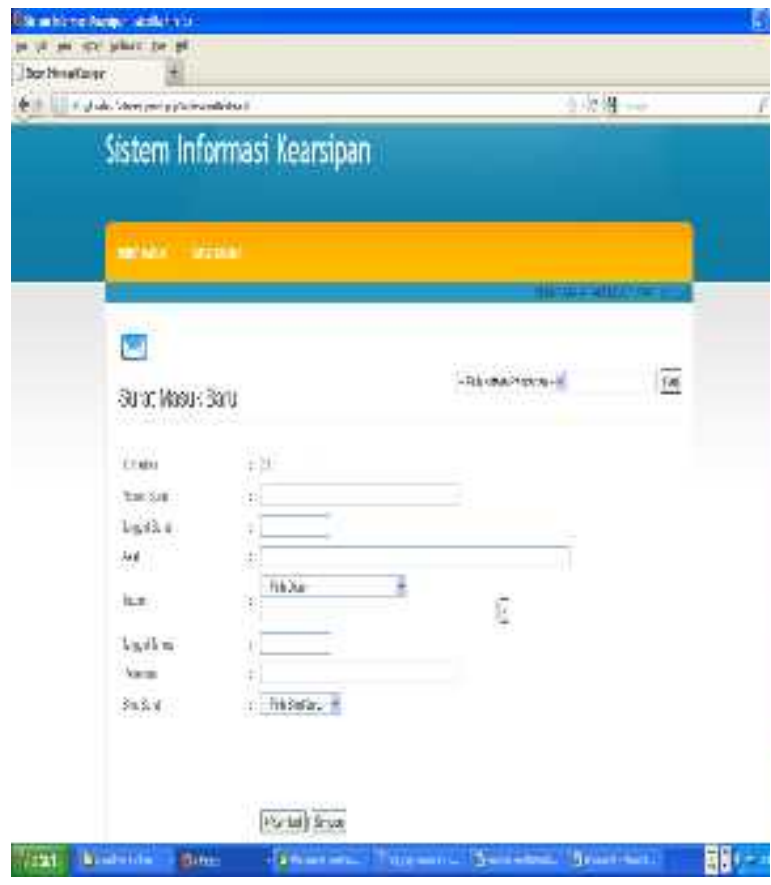

Gambar 10 Tampilan pengisian surat masuk baru

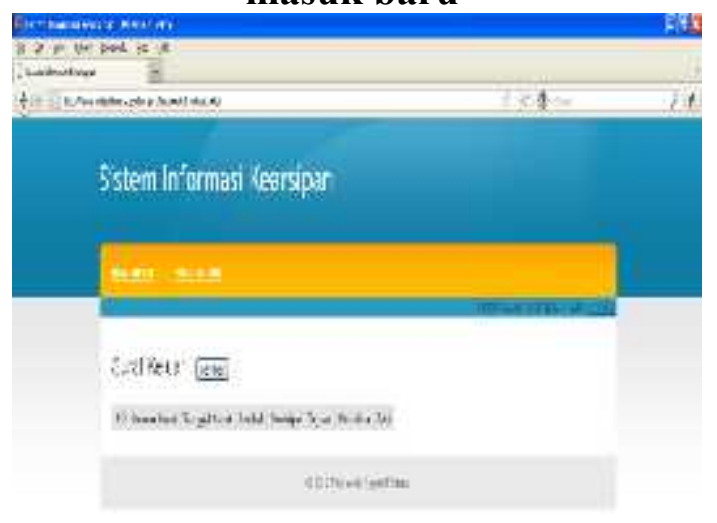

Gambar 11. Tampilan surat keluar

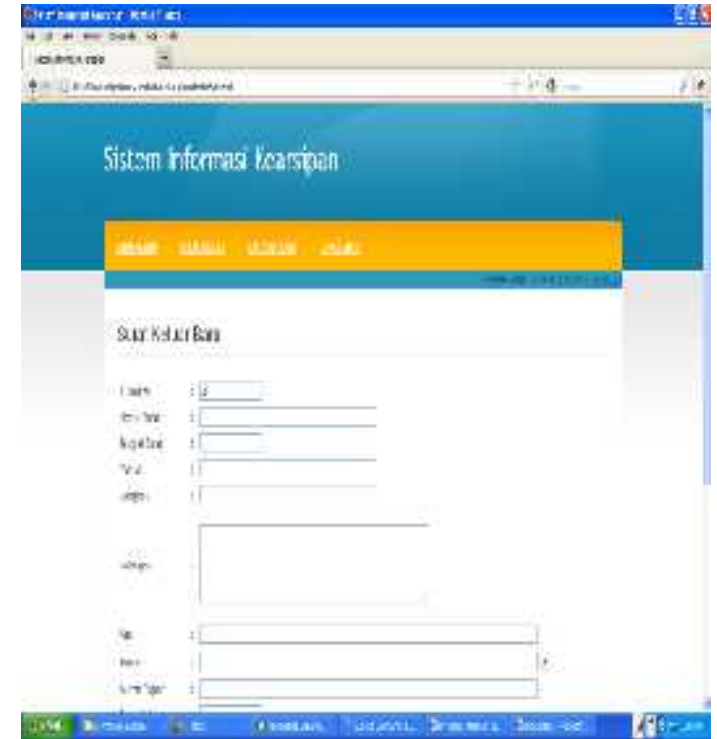

Gambar 11. Tampilan surat keluar baru

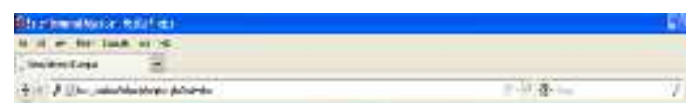

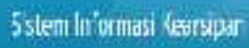

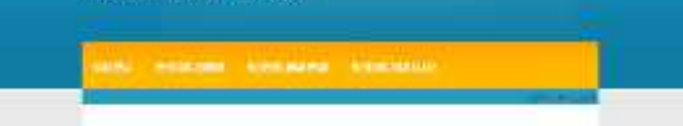

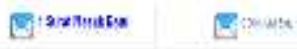

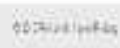

Gambar 12 Tampilan pemberitahuan surat masuk 


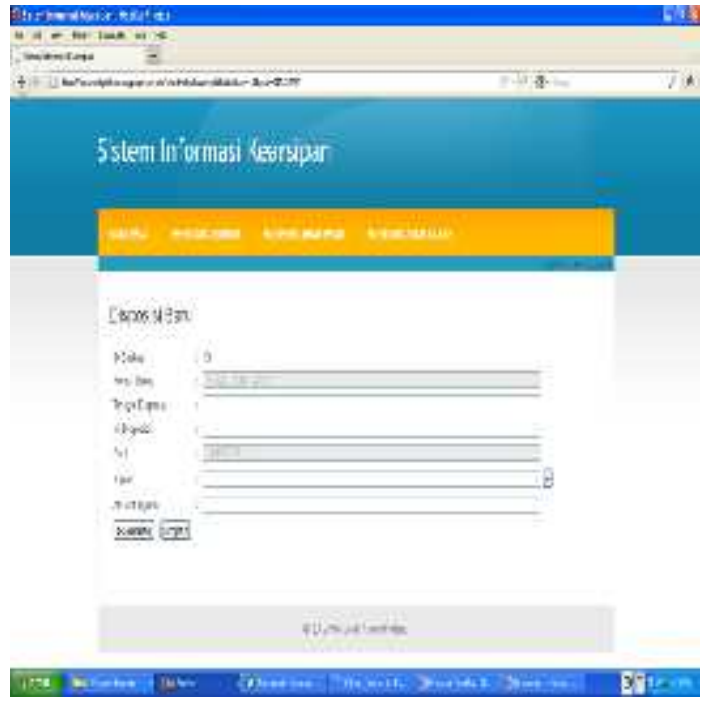

Gambar 13 Tampilan disposisi baru
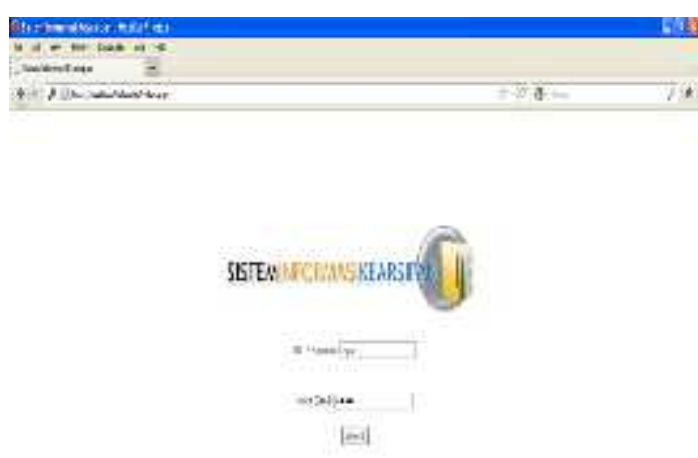

\section{Gambar 14 Tampilan Login sebagai ketua jurusan}

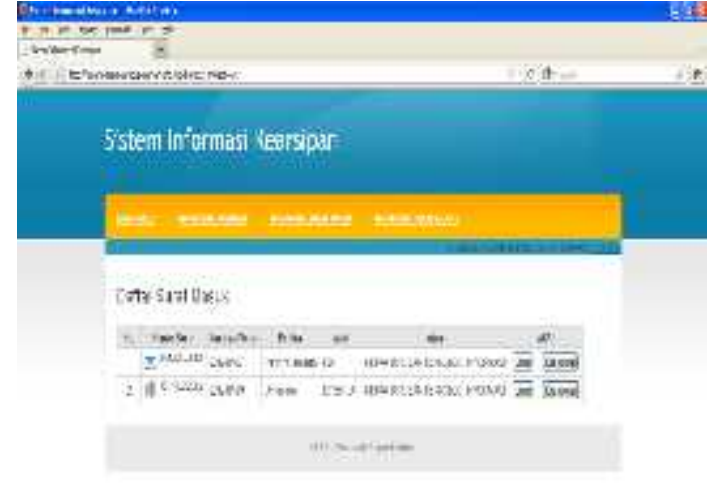

\section{Gambar 15 Tampilan daftar surat masuk jurusan}

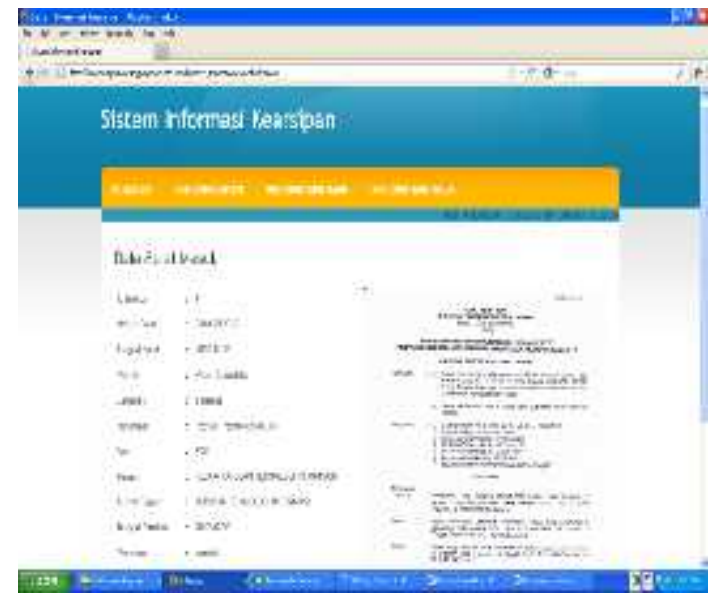

Gambar 16 Tampilan data surat masuk jurusan

\section{Pembahasan}

Sistem yang dihasilkan merupakan aplikasi yang dijalankan berbasis web, dapat diakses oleh banyak pengguna di waktu yang bersamaan melalui browser di komputer masing-masing dengan mengakses alamat yang ditentukan. Pengguna sistem ini terdiri dari pimpinan, struktural, administrator, dan adm. Sistem ini dapat menerima input surat masuk dan surat keluar dari internal dan eksternal Politeknik dengan cara melakukan scan terlebih dahulu terhadap surat masuk dan surat keluar tersebut, dapat 
menampilkan surat masuk kepada pimpinan dan mengetahui apakah surat tersebut sudah dilakukan disposisi atau belum dan kalau sudah dilakukan disposisi, kepada siapa surat tersebut di disposisikan juga dapat dilihat pada sistem ini. Bagi staf pengajar, jika ada surat masuk hanya bisa dilihat oleh adm jurusan saja dan adm jurusan yang akan menyampaikan kepada staf pengajar yang bersangkutan nantinya. Sistem juga menyediakan fasilitas untuk melakukan pencarian terhadap surat masuk dan surat keluar. Sistem ini dibangun menggunakan bahasa pemrograman PHP dan basisdata MySQL Server.

Kelebihan sistem ini adalah dapat menghemat kertas dan tempat penyimpanan fisik. Pengisian data kedalam sistem dilakukan oleh admin serta melakukan scan terhadap surat masuk dan surat keluar. Dengan tersedianya sistem ini secara online maka semua pengguna dapat mengakses kapanpun dan dimanapun.

\section{KESIMPULAN DAN SARAN}

\section{Kesimpulan}

1. Sistem Informasi Kearsipan Politeknik Negeri Padang ini merupakan aplikasi berbasis web yang dapat digunakan untuk pengolahan surat masuk dan surat keluar secara terintegrasi, dan dapat diakses secara online oleh banyak pengguna pada waktu yang bersamaan.

2. Sistem ini dapat memudahkan, menghemat waktu dan mengurangi kesalahan dalam memberikan surat masuk dan surat keluar.

3. Sistem ini dapat menyediakan informasi secara cepat tentang surat masuk dan surat keluar yang ada di Politeknik kepada pimpinan untuk kemudian dapat ditindaklanjuti dan kepada administrasi.

4. Kelebihan sistem ini adalah dapat menghemat kertas dan tempat penyimpanan fisik, pengolahannya tidak membutuhkan tenaga kerja khusus dan hasil pengolahannya langsung dapat diakses oleh pihak-pihak yang berkepentingan.

5. Sedangkan keterbatasannya adalah hanya terbatas untuk pimpinan dan administrasi saja sedangkan staf pengajar atau dosen dosen belum bisa melihat surat masuk dan surat keluar dosen yang bersangkutan .

\section{Saran}

Sistem ini dapat dikembangkan untuk menambah user sehingga penyampaian surat menjadi lebih cepat dan tepat.

\section{UCAPAN TERIMA KASIH}

1. Bapak Ir. Aidil Zamri, MT selaku Direktur Politeknik Negeri Padang

2. Bapak Drs, Roswaldi. SK, M.Kom selaku Kepala UPT PPKM

3. Bapak Drs. Erwadi Bakar, M.Kom selaku Ketua Jurusan Teknologi Informasi

4. Seluruh pimpinan, staf pengajar dan civitas akademika Politeknik Negeri Padang terutama Jurusan Teknologi Informasi yang telah membantu hingga penelitian ini selesai.

\section{DAFTAR PUSTAKA}

http://repository.ipb.ac.id/handle/123 456789/33842

Pudji Muljono 
MANAJEMEN

ARSIP

DENGAN

SISTEM

MODERN

http://ejournal.unud.ac.id/new/search

. html

Rancang Bangun Sistem

Informasi Persuratan dan

Kearsipan Universitas

Udayana menggunakan

Paradigma Pemrograman

Berbasis Objek, Gusti Agung

Ayu Putri.

http://www.ebooklibs.com/word-

documents/view.php? file $=$ htt

$\mathrm{p}: / /$ server-

aplikasi.dephub.go.id

Petunjuk Penggunaan Aplikasi

Sistem Informasi Persuratan

Elektronik Berbasis Intranet,

Pusat Data Dan Informasi

Kementrian Perhubungan.

Abdul Kadir, 2008. Belajar Database Menggunakan MySQL, Andi Offset.

Abdul Kadir, 2002, Dasar Pemograman Web Dinamis menggunakan PHP, Penerbit Andi Offset, Yogyakarta).

HusniI, Pohan, 2002. SQL Tutorial, Informatika, Bandung,

Jogianto, H.M, 2005, Analisa dan Disain Sistem Informasi , Penerbit Andi Offset, Yogyakarta.

Kristanto, Andri, 2003, Perancangan

Sistem Informasi dan Aplikasinya, Penerbit Gaya Media, Yogyakarta.

Ronal Hadi, dkk. Tracer Study untuk Alumni Program Studi Teknik Komputer Politeknik Negeri Padang, Politeknik Negeri Padang, 2011.

Wahana Komputer, 2010, Panduan Belajar MySQL Database Server. Mediakita,.
Yulherniwati, dkk. Rancang Bangun Aplikasi Tracer Study untuk Alumni Program Studi Manajemen Informatika Politeknik Negeri Padang, Politeknik Negeri Padang, 
ISSN :2085-6989 